\title{
The curing behavior and properties of phthalonitrile resins using ionic liquids as a new class of curing agents
}

\author{
K. Cheng, J. B. Lv, J. Z. Ma, J. H. Hu, C. Chen, K. Zeng*', G. Yang \\ State Key Laboratory of Polymer Materials Engineering, College of Polymer Science and Engineering, Sichuan \\ University, 610065 Chengdu, P. R. China
}

Received 2 May 2017; accepted in revised form 24 June 2017

\begin{abstract}
Binary blends composed of 1,3-bis (3,4-dicyanophenoxy) benzene (3BOCN) and ionic liquids (ILs) with different molecular structures were prepared. The curing behavior of these 3BOCN/ILs blends were studied by thermogravimetric analysis (TGA), differential scanning calorimetry (DSC) and rheological analysis. The study suggested that the blends possessed a wide processing window and the structures of ILs (anion, cation and alkyl chain length at cation) had an effect on curing behavior. The $3 \mathrm{BOCN} /[\mathrm{EPy}] \mathrm{BF}_{4}$ resins were prepared at elevated temperature. IR spectra of the resins showed that there were triazine and isoindoline formed in curing process. The TGA and dynamic mechanical analysis (DMA) revealed that the resins have excellent thermal stability together with high storage modulus and high glass transition temperature $\left(T_{\mathrm{g}}\right)$. Dielectric properties, long term oxidative aging and water uptake measurements of the resins suggested the IL brought some unique properties to the resins.
\end{abstract}

Keywords: thermoseting resins, thermal properties, phthalonitrile, ionic liquids, curing behavior

\section{Introduction}

As a class of high-temperature/performance polymer, phthalonitrile (PN) resins have many excellent properties such as high thermal and oxidative stability, flame retardance, the absence of a $T_{\mathrm{g}}$ before the thermal decomposition temperature, water and chemical resistance $[1,2]$. These excellent high-temperature properties make the PN resins attractive for many military and civilian advanced technological applications, such as composite matrices [3, 4], adhesives [5], electrical conductors [6], and carbon precursors [7].

However, the polymerization of neat PN compound is extremely sluggish, the high curing-temperature of PN resins limited their further applications [1]. In order to address this problem, considerable research efforts have been expended on the development for the curing agent. To date, lots of Lewis acids/bases curing agent, such as metallic salts, strong organic acids, strong organic acids/amine salts and active hydrogen-containing heterocyclic structures have been developed and used [8-17]. In addition to the traditional Lewis acids/bases, our laboratory also reported the cooperative curing effect between phthalonitrile and methyl tetrahydrophthalic anhydride end-capped imide compound (MODA) [18, 19].

To find more kinds of efficient curing agents, we have done a lot of work. Recently we found that a variety of ionic liquids (ILs) could promote the curing process of PN. ILs are organic salts that melt at very low temperature (empirically bellow $100^{\circ} \mathrm{C}$ ) $[20,21]$, which are composed of bulky and nonsymmetrical organic cations (such as pyridinium, pyrrolidium, imidazolium, tetraalkyl ammonium and tetraalkyl phosphonium) and numerous different organic or inorganic anions (such as tetrafluoroborate, hexafluorophosphate, 
chloride). Different from molecular liquids, ILs have many outstanding properties, for instance, high ther$\mathrm{mal} / \mathrm{chemical}$ stability in the liquid state, vanishingly low vapor pressure, wide electrochemical window and the ability to dissolve easily for a wide range of inorganic/organic materials. ILs are also called 'designer solvents' because a long list of ILs with different proprieties can be obtained by varying the combinations of cations and anions. It was reported that the number of possible combinations of ILs can be up to $10^{18}$ due to the ability to interchange their corresponding cationic/anionic moieties [22]. Besides, there has also been research work published on the use of ILs for polymerization reactions. In carbon nanotubes modified epoxy compositions, ILs could act as both catalytic epoxy resin crosslinkers and carbon nanofiller dispersing agent [23, 24]. With so many unique advantages, ILs may provide extremely large number of potential efficient and functional curing agents for PN.

The curing of phthalonitrile resins has been a challenging problem in this area, and related research on curing behavior of PN is an important step in solving this problem. The structures of ILs are diverse by varying the combination of cations and anions, consequently, they are suitable model system for researching the correlation between the structure of curing agent and PN curing behavior. In this study, we chose six kinds of common ILs as curing agents for the first time. They are $N$-ethylpyridinium tetrafluoroborate ([EPy]BF 4 ), $N$-ethylpyridinium hexafluorophosphate ([EPy] $\left.\mathrm{PF}_{6}\right)$, 1-ethyl-3-methylimidazolium Tetrafluoroborate $\left(\left[\mathrm{C}_{2} \mathrm{mim}\right] \mathrm{BF}_{4}\right)$, 1-ethyl-3-methylimidazolium hexafluorophosphate $\left(\left[\mathrm{C}_{2} \mathrm{mim}\right] \mathrm{PF}_{6}\right)$, 1-butyl-3-methylimidazolium Tetrafluoroborate $\left(\left[\mathrm{C}_{4} \mathrm{mim}_{\mathrm{B}}\right] \mathrm{BF}_{4}\right)$, 1-Octadecyl-3-methylimidazolium Tetrafluoroborate $\left(\left[\mathrm{C}_{18} \mathrm{mim}\right] \mathrm{BF}_{4}\right)$, each of them has the different cation or anion from another. The curing behaviors of 3BOCN/IL blends were investigated by TGA, DSC and rheological analysis. The thermal and dielectric properties of $3 \mathrm{BOCN} /[\mathrm{EPy}] \mathrm{BF}_{4}$ system were studied, the results showed that the cured resins possessed high glass transition temperatures, excellent thermal and thermal oxidation stabilities, unique dielectric properties. And the long term oxidative aging and water uptake properties were also studied. These works may open up a new research direction of the PN modification.

\section{Experiment}

\subsection{Materials}

Resorcinol (99.5\%), dimethylsulfoxide (DMSO, AR), and Potassium carbonate $\left(\mathrm{K}_{2} \mathrm{CO}_{3} 99.0 \%\right)$ were supplied by Chengdu Kelong Chemical Reagent Co., Ltd, Chengdu, China. 4-Nitrophthalonitrile (99\%) was purchased from Hong Kong's Ming Tai Prosperity Chemical Co., Ltd, Hong Kong, China. [EPy] $\mathrm{BF}_{4}$, $[\mathrm{EPy}] \mathrm{PF}_{6},\left[\mathrm{C}_{2} \mathrm{mim}\right] \mathrm{BF}_{4},\left[\mathrm{C}_{2} \mathrm{mim}\right] \mathrm{PF}_{6},\left[\mathrm{C}_{4} \mathrm{mim}\right] \mathrm{BF}_{4}$ and $\left[\mathrm{C}_{18} \mathrm{mim}\right] \mathrm{BF}_{4}$ were purchased from Chengjie Chemical Co., Ltd, Shanghai, China. All starting materials were of reagent grade and used without further purification.

\subsection{Synthesis of 1,3 -bis}

(3, 4-dicyanophenoxy) benzene 3BOCN

The phthalonitrile monomer $3 \mathrm{BOCN}$ was synthesized depending on a reported literature [13]. (Figure 1) ${ }^{1} \mathrm{H}$ NMR (300 MHz, DMSO- $\left.d_{6}\right): \delta 8.11-8.14$ (d, 2H, Ar-H), 7.91-7.92 (d, 2H, Ar-H), 7.60-7.63 (dd, 1H, Ar-H), 7.53-7.59 (dd, 2H, Ar-H), 7.13-7.14 (s, 2H, Ar-H), 7.12 (s, 1H, Ar-H).

\subsection{Preparation of the $3 \mathrm{BOCN} / \mathrm{IL}$ blends}

All kinds of 3BOCN/ILs blends (molar ratio 1.255:1, $2.152: 1,4.842: 1$ ) were prepared by transferring the compounds to a mortar and ground into a smooth paste under the infrared lamps.

\subsection{Preparation of phthalonitrile polymer networks and samples}

Resin- 1 and Resin-2 were fabricated by degassing $3 \mathrm{BOCN} /[\mathrm{EPy}] \mathrm{BF}_{4}$ blends (molar ratio 4.842:1 and

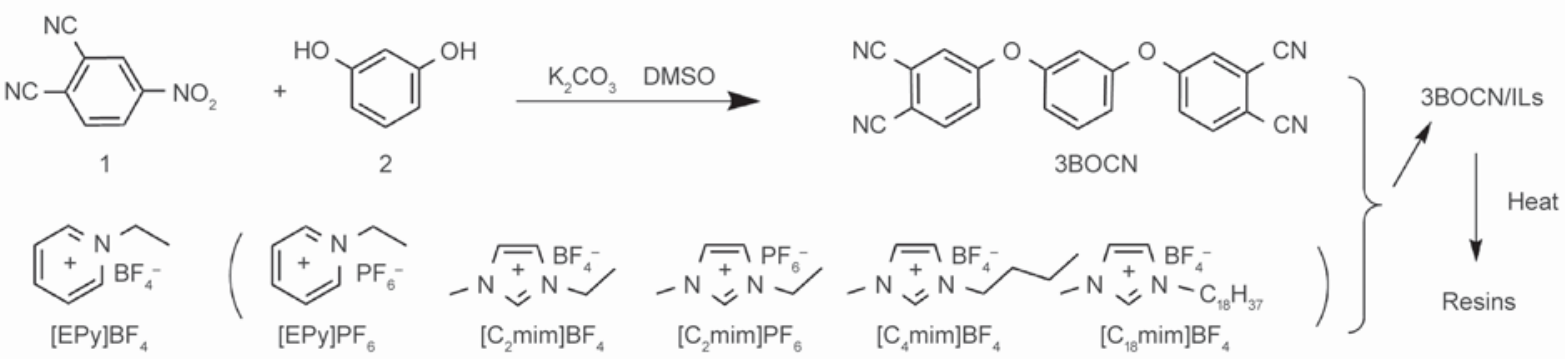

Figure 1. Synthesis of monomer and curing of 3BOCN/ILs blends 
2.152:1) in a flask $(-0.04 \mathrm{MPa})$ at $180^{\circ} \mathrm{C}$ for $10 \mathrm{~min}$ with stirring, and then the melted $3 \mathrm{BOCN} /\left[\mathrm{EPy}^{\mathrm{B}} \mathrm{BF}_{4}\right.$ mixtures were poured into the preheated mold, placed in an oven, and heated under $\mathrm{N}_{2}$ at $220^{\circ} \mathrm{C}$ for $8 \mathrm{~h}, 245^{\circ} \mathrm{C}$ for $8 \mathrm{~h}$. After cooling, the samples were removed from mold, free-standing samples were cured under an inert atmosphere of argon at elevated temperatures of $270^{\circ} \mathrm{C}$ for $8 \mathrm{~h}, 295^{\circ} \mathrm{C}$ for $8 \mathrm{~h}$, $320^{\circ} \mathrm{C}$ for $8 \mathrm{~h}, 350^{\circ} \mathrm{C}$ for $8 \mathrm{~h}, 380^{\circ} \mathrm{C}$ for $8 \mathrm{~h}$.

Polymer samples for DMA were sanded to $30.0 \times$ $12.5 \times 3.0 \mathrm{~mm}^{3}$. Samples for dielectric measurements were $20.0 \times 20.0 \times 1.8 \mathrm{~mm}^{3}$. Samples for water uptake measurements were approximately $50 \times 13 \times 2 \mathrm{~mm}^{3}$, and samples for oxidative aging studies were approximately $1.5 \times 1.5 \times 1.5 \mathrm{~mm}^{3}$.

\subsection{Characterizations}

${ }^{1} \mathrm{H}$ nuclear magnetic resonance (NMR, $300 \mathrm{MHz}$ ) was obtained with a Bruker Avance-300 NMR spectrometer (Bruker, USA) with DMSO- $d_{6}$ as the solvent and tetramethylsilane (TMS) as the internal standard. Fourier transform infrared spectroscopy (FT-IR) were obtained from a Nicolet-460 FT-IR spectrometer (Thermo Fisher Scientific, USA) in $\mathrm{KBr}$ pellets in the range of $400-4000 \mathrm{~cm}^{-1}$. Thermo-gravimetric analysis (TGA) was performed from 40 to $800^{\circ} \mathrm{C}$ at a heat rate of $10^{\circ} \mathrm{C} \cdot \mathrm{min}^{-1}$ in nitrogen or air at the flow rate of $60 \mathrm{~mL} \cdot \mathrm{min}^{-1}$ by a TA Instruments Q500 thermo-gravimetric analyzer (TA, USA). Differential scanning calorimetry (DSC) was performed on a TA Instrument Q200 differential scanning calorimeter (TA, USA) under nitrogen atmosphere $\left(50 \mathrm{~mL} \cdot \mathrm{min}^{-1}\right)$ at a heating rate of $10^{\circ} \mathrm{C} \cdot \mathrm{min}^{-1}$. Dynamic viscosity measurements were done by using a TA Instruments AR 2000 rheometer (TA, USA) in conjunction with environmental testing chamber for temperature control. The rheological characterization of 3BOCN-IL blends was investigated after the powders melted between the $24 \mathrm{~mm}$ diameter parallel plates at a strain of $2.5 \cdot 10^{-4}$ and a frequency of $1 \mathrm{~Hz}$. The mixtures were tested from 40 to $380^{\circ} \mathrm{C}$ in air at a heating rate of $5^{\circ} \mathrm{C} \cdot \mathrm{min}^{-1}$. And the mixtures melt viscosity was also detected at 200, 220, 240, $260^{\circ} \mathrm{C}$ in air as a function of time respectively. Dynamic mechanical analysis (DMA) was performed using a TA Instruments Q800 dynamic mechanical analyzer (TA, USA) under three-point bending mode, and the measurement was performed in nitrogen atmosphere from 40 to $450^{\circ} \mathrm{C}$ with a heating rate of $5^{\circ} \mathrm{C} \cdot \mathrm{min}^{-1}$ and at a frequency of $1 \mathrm{~Hz}$ and a strain

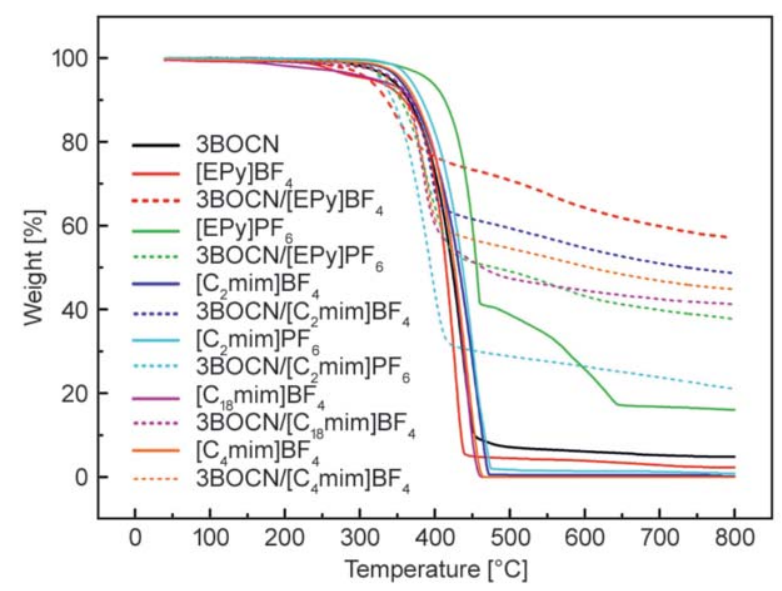

Figure 2. TGA curves of $3 \mathrm{BOCN}$, ILs and $3 \mathrm{BOCN} / \mathrm{ILs}$ blends (molar ratio 1.255:1) at a heating rate of $10^{\circ} \mathrm{C} / \mathrm{min}$

of $2.5 \cdot 10^{-2} \%$. Dielectric measurements were carried out at different frequencies ranging from $10^{-2}-10^{7} \mathrm{~Hz}$ at room temperature using Novocontrol Concept 50 Broadband Dielectric Spectrometer (Novocontrol Technolohies, Germany).

\section{Results and discussion}

\subsection{Polymerization behaviors of $3 \mathrm{BOCN} / \mathrm{IL}$ blends}

Figure 2 shows the TGA curves of $3 \mathrm{BOCN}$, ILs and the 3BOCN/ILs blends (molar ratio 1.255:1) in nitrogen at the heating rate of $10^{\circ} \mathrm{C} / \mathrm{min}$. The $T_{5 \%}$ of every kind of ILs we used are over $310^{\circ} \mathrm{C}$ (Table 1), suggesting the high thermal stability of ILs, which is of great importance for phthalonitrile curing-agents. The weight decrease of 3BOCN/ILs blends slowed down at around $400{ }^{\circ} \mathrm{C}$ and the residual weight retention at $800^{\circ} \mathrm{C}$ was higher than $3 \mathrm{BOCN}$ and corresponding ILs, indicating that the polymerization of $3 \mathrm{BOCN}$ was promoted by ILs during the heating run.

Table 1. The TGA data of $3 \mathrm{BOCN}$, ILs and $3 \mathrm{BOCN} / \mathrm{ILs}$ blends in $\mathrm{N}_{2}$ at a heating rate of $10^{\circ} \mathrm{C} / \mathrm{min}$

\begin{tabular}{|c|c|c|c|}
\hline & \multirow{2}{*}{$\begin{array}{l}T_{5 \%} \\
{\left[{ }^{\circ} \mathrm{C}\right]}\end{array}$} & \multicolumn{2}{|c|}{$\begin{array}{c}\text { Char yield at } 800^{\circ} \mathrm{C} \\
{[\%]}\end{array}$} \\
\hline & & Pure $^{a}$ & Blend $^{b}$ \\
\hline $3 \mathrm{BOCN}$ & 341.00 & 4.83 & - \\
\hline$[\mathrm{EPy}] \mathrm{BF}_{4}$ & 312.55 & 2.27 & 57.22 \\
\hline$[\mathrm{EPy}] \mathrm{PF}_{6}$ & 391.30 & 16.06 & 37.82 \\
\hline$\left[\mathrm{C}_{2} \mathrm{mim}\right] \mathrm{BF}_{4}$ & 352.30 & 0.10 & 48.73 \\
\hline$\left[\mathrm{C}_{2} \mathrm{mim}\right] \mathrm{PF}_{6}$ & 366.20 & 0.31 & 21.17 \\
\hline$\left[\mathrm{C}_{4} \mathrm{mim}\right] \mathrm{BF}_{4}$ & 356.28 & 0.00 & 44.88 \\
\hline$\left[\mathrm{C}_{18} \mathrm{mim}\right] \mathrm{BF}_{4}$ & 318.44 & 0.00 & 41.33 \\
\hline
\end{tabular}

aPure $3 \mathrm{BOCN}$ or ILs

${ }^{\mathrm{b}}$ The blend of $3 \mathrm{BOCN}$ and every kind of IL at 1.255:1 molar ratio 
Table 2. The DSC data of $3 \mathrm{BOCN}$ and $3 \mathrm{BOCN} / \mathrm{ILs}$ blends in $\mathrm{N}_{2}$ at a heating rate of $10^{\circ} \mathrm{C} / \mathrm{min}$

\begin{tabular}{|l|c|c|c|c|}
\hline & $\begin{array}{c}\boldsymbol{T}_{\mathbf{m}_{1}}{ }^{\mathbf{a}} \\
{\left[{ }^{\circ} \mathbf{C}\right]}\end{array}$ & $\begin{array}{c}\boldsymbol{T}_{\mathbf{m}_{2}}{ }^{\mathbf{a}} \\
{\left[{ }^{\circ} \mathbf{C}\right]}\end{array}$ & $\begin{array}{c}\boldsymbol{T}_{\mathbf{0}}{ }^{\mathbf{b}} \\
{\left[{ }^{\circ} \mathbf{C}\right]}\end{array}$ & $\begin{array}{c}\boldsymbol{T}_{\mathbf{p}}{ }^{\mathbf{c}} \\
{\left[{ }^{\circ} \mathbf{C}\right]}\end{array}$ \\
\hline $3 \mathrm{BOCN}$ & - & 184.38 & - & - \\
\hline $3 \mathrm{BOCN} /[\mathrm{NPy}] \mathrm{BF}_{4}$ & 48.60 & 171.44 & 215.75 & 271.20 \\
\hline $3 \mathrm{BOCN} /\left[\mathrm{NPy}_{\mathrm{BOCN}} /\left[\mathrm{C}_{2} \mathrm{mim}_{6}\right] \mathrm{BF}_{4}\right.$ & 97.33 & 168.20 & 276.50 & 306.97 \\
\hline $3 \mathrm{BOCN} /\left[\mathrm{C}_{2} \mathrm{mim}\right] \mathrm{PF}_{6}$ & 59.91 & 167.54 & 235.43 & 275.51 \\
\hline $3 \mathrm{BOCN} /\left[\mathrm{C}_{4} \mathrm{mim}\right] \mathrm{BF}_{4}$ & $<40$ & 166.56 & 327.83 & $>350$ \\
\hline $3 \mathrm{BOCN} /\left[\mathrm{C}_{18} \mathrm{mim}\right] \mathrm{BF}_{4}$ & 59.58 & 168.53 & 258.28 & 275.17 \\
\hline
\end{tabular}

${ }^{\mathrm{a}}$ Melting points

${ }^{b}$ The curing onset temperature

${ }^{\mathrm{c}}$ The peak temperature of the exothermic area

The more $3 \mathrm{BOCN}$ was cured into thermoset network, the higher residual weight of blend at $800^{\circ} \mathrm{C}$. The char yield order of $3 \mathrm{BOCN} / \mathrm{ILs}$ blend at $800^{\circ} \mathrm{C}$ showed that the mass fraction of $3 \mathrm{BOCN}$ cured by IL decreased in ILs order: [EPy] $\mathrm{BF}_{4}>\left[\mathrm{C}_{2} \mathrm{mim}\right] \mathrm{BF}_{4}>$ $\left[\mathrm{C}_{4} \mathrm{mim}\right] \mathrm{BF}_{4}>\quad\left[\mathrm{C}_{18} \mathrm{mim}\right] \mathrm{BF}_{4}>\quad[\mathrm{EPy}] \mathrm{PF}_{6}>$ $\left[\mathrm{C}_{2} \mathrm{mim}\right] \mathrm{PF}_{6}$. This order reflected the catalytic activity of ILs in some way.

The thermal behavior of 3BOCN/ILs blends (molar ratio $1.255: 1$ ) were also studied by DSC at the heating rate of $10^{\circ} \mathrm{C} / \mathrm{min}$ in nitrogen (Figure 3 , Table 2).

There were two endothermic peaks in 3BOCN/[EPy] $\mathrm{BF}_{4}, 3 \mathrm{BOCN} /[\mathrm{EPy}] \mathrm{PF}_{6}$ and $3 \mathrm{BOCN} /\left[\mathrm{C}_{2} \mathrm{mim}\right] \mathrm{PF}_{6}$ blends corresponding to the melting transition of IL and $3 \mathrm{BOCN}$. $3 \mathrm{BOCN} /\left[\mathrm{C}_{2} \mathrm{mim}\right] \mathrm{BF}_{4}$ and $3 \mathrm{BOCN} /$ $\left[\mathrm{C}_{2} \mathrm{mim}\right] \mathrm{BF}_{4}$ exhibited only one melting point between 40 and $350^{\circ} \mathrm{C}$, because the melting point of $\left[\mathrm{C}_{2} \mathrm{mim}\right] \mathrm{BF}_{4}$ and $\left[\mathrm{C}_{2} \mathrm{mim}\right] \mathrm{BF}_{4}$ is blow $40^{\circ} \mathrm{C}$. Unexpectedly, we found another small endothermic peak at $140.5^{\circ} \mathrm{C}$ in $3 \mathrm{BOCN} /\left[\mathrm{C}_{18} \mathrm{mim}\right] \mathrm{BF}_{4}$ curve between the melting point of $\left[\mathrm{C}_{18} \mathrm{mim}\right] \mathrm{BF}_{4}$ and $3 \mathrm{BOCN}$, this phenomenon might attribute to that a portion of $3 \mathrm{BOCN}$ dissolved in $\left[\mathrm{C}_{18} \mathrm{mim}\right] \mathrm{BF}_{4}$ precipitated a new crystal form after $3 \mathrm{BOCN} /\left[\mathrm{C}_{18} \mathrm{mim}\right] \mathrm{BF}_{4}$ blend cool down. Curve of pure $3 \mathrm{BOCN}$ showed no exothermic transition at elevated temperature indicating $3 \mathrm{BOCN}$ was hard to polymerize by itself. While the polymerization of $3 \mathrm{BOCN}$ could be promoted by ILs. The curing onset temperature of blends increased in ILs order: $[\mathrm{EPy}] \mathrm{BF}_{4}<\left[\mathrm{C}_{18} \mathrm{mim}\right] \mathrm{BF}_{4}<\left[\mathrm{C}_{2} \mathrm{mim}\right] \mathrm{BF}_{4}<$ $\left[\mathrm{C}_{4} \mathrm{mim}\right] \mathrm{BF}_{4}<[\mathrm{EPy}] \mathrm{PF}_{6}<\left[\mathrm{C}_{2} \mathrm{mim}\right] \mathrm{PF}_{6}$, which had some correlation to char yield order of $3 \mathrm{BOCN} / \mathrm{ILs}$ blends at $800^{\circ} \mathrm{C}$ : $[\mathrm{EPy}] \mathrm{BF}_{4}>\left[\mathrm{C}_{2} \mathrm{mim}\right] \mathrm{BF}_{4}>$ $\left[\mathrm{C}_{4} \mathrm{mim}\right] \mathrm{BF}_{4}>\left[\mathrm{C}_{18} \mathrm{mim}\right] \mathrm{BF}_{4}>[\mathrm{EPy}] \mathrm{PF}_{6}>$ $\left[\mathrm{C}_{2} \mathrm{mim}\right] \mathrm{PF}_{6}$. These rankings are the reflection of ILs catalytic activity in different aspects. Particularly, the difference in rank of $\left[\mathrm{C}_{18} \mathrm{mim}\right] \mathrm{BF}_{4}$ may due to that

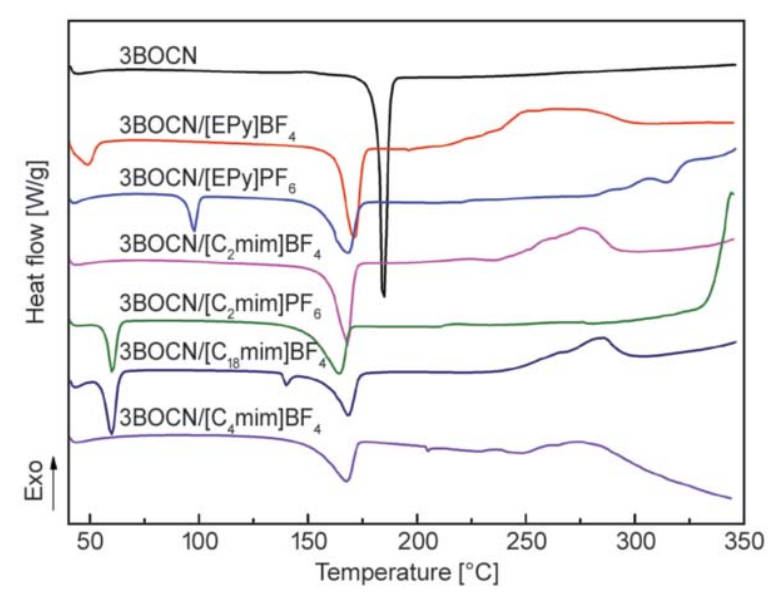

Figure 3. DSC curves of $3 \mathrm{BOCN}$ and $3 \mathrm{BOCN} / \mathrm{ILs}$ blends (molar ratio $1.255: 1$ ) at a heating rate of $10^{\circ} \mathrm{C} / \mathrm{min}$

the molecular weight of $\left[\mathrm{C}_{18} \mathrm{mim}\right] \mathrm{BF}_{4}$ is much higher than other kinds of ILs. When 3BOCN was blended with different ILs in fixed molar ratio, the mass ratio of $3 \mathrm{BOCN}$ in $3 \mathrm{BOCN} /\left[\mathrm{C}_{18} \mathrm{mim}\right] \mathrm{BF}_{4}$ was much lower than others leading to a rank down in chair yield. From the TGA and DSC data, it can be found that the catalytic activity of ILs changes with the structures of cation and decreases in anion order: $\left[\mathrm{Bf}_{4}\right]>\left[\mathrm{Pf}_{6}\right]$.

To learn more about the polymerization behavior of 3BOCN/ILs blends as well as the relationship between ILs structure and curing behavior, dynamic viscosity measurements were employed. In Figure $4 \mathrm{a}$, the melt viscosities of 3BOCN/ILs blends were determined as function of temperature at the heating rate of $5{ }^{\circ} \mathrm{C} / \mathrm{min}$. In every curve of the blends, we could observe a rapid decrease in viscosity around the melting point of $3 \mathrm{BOCN}$ and the melt viscosities were very low (3 4 Pa.s) which was evidence of their good processability. With the increase of temperature, the viscosities of $3 \mathrm{BOCN} /[\mathrm{EPy}] \mathrm{BF}_{4}$ and $3 \mathrm{BOCN} /\left[\mathrm{C}_{18} \mathrm{mim}\right] \mathrm{BF}_{4}$ moved up sharply at 306.0 and $319.7^{\circ} \mathrm{C}$ respectively, while the rest of blends didn't have obvious viscosity transition, indicating that $[\mathrm{EPy}] \mathrm{BF}_{4}$ and $\left[\mathrm{C}_{18} \mathrm{mim}\right] \mathrm{BF}_{4}$ have higher catalytic activity to promote the curing of $3 \mathrm{BOCN}$ than other ILs. The Figure $4 \mathrm{a}$ also revealed that the process windows of all 3BOCN/ILs blends were very large $\left(>130^{\circ} \mathrm{C}\right)$, which is good for the fabrication of large size composite sections.

In Figure $4 b$ and $4 c$ the melt viscosities of $3 \mathrm{BOCN} / \mathrm{ILs}$ blends were determined as function of time at 260 (Figure $4 \mathrm{~b}$ ) and $240^{\circ} \mathrm{C}$ (Figure 4c). The time when the blends began to polymerize quickly varied with ILs. $3 \mathrm{BOCN} /[\mathrm{EPy}] \mathrm{BF}_{4}$ blend was the fastest to 

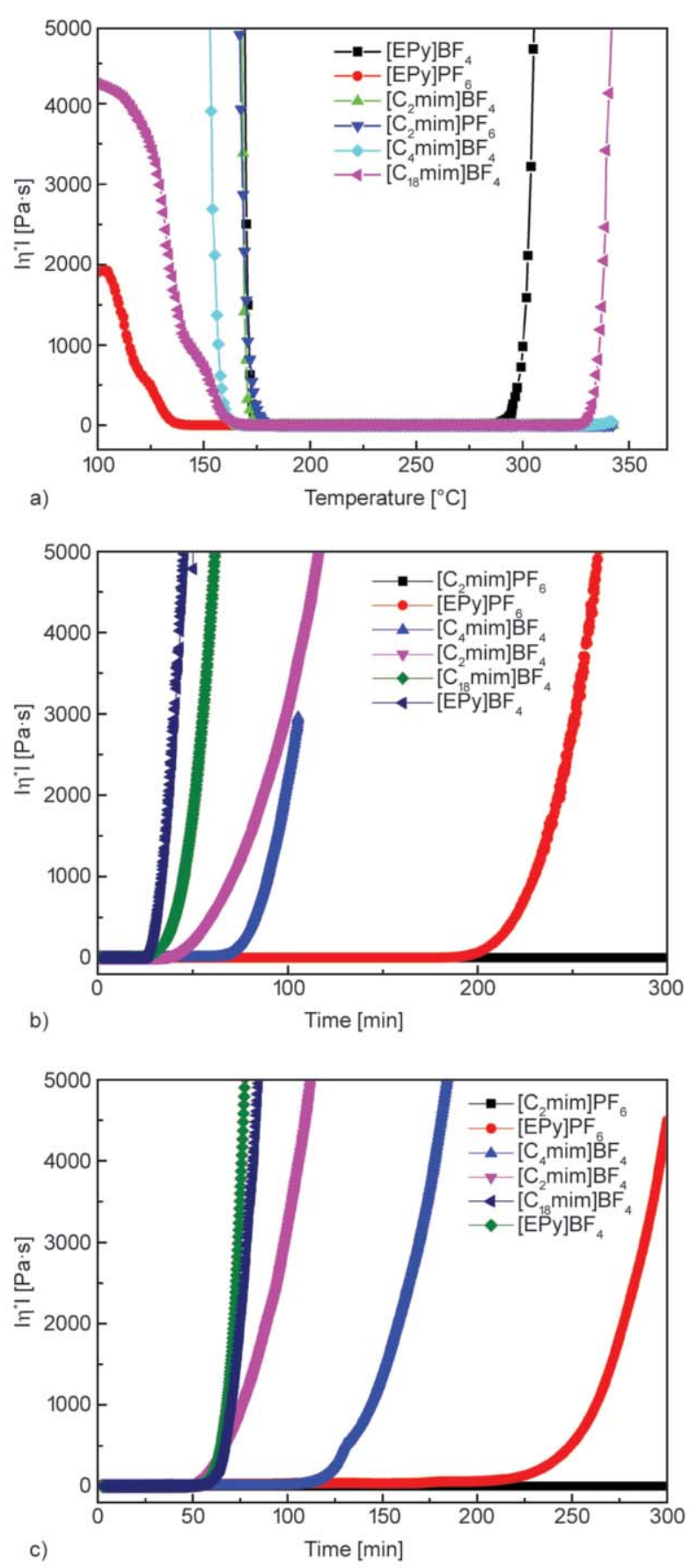

Figure 4. Melt viscosity curves for 3BOCN/ILs (molar ratio 1.255:1). (a): Melt viscosity vs. temperature at heating rate of $5^{\circ} \mathrm{C} / \mathrm{min}$; (b) and (c): Melt viscosity vs. time at 260 and $240^{\circ} \mathrm{C}$ polymerize. While $3 \mathrm{BOCN} /\left[\mathrm{C}_{2} \mathrm{mim}\right] \mathrm{PF}_{6}$ blend was the most sluggish, its viscosity kept low during the test process (600 minutes). The gelation points were showed in Table 3, gelation time increased in ILs order at both 260 and $240^{\circ} \mathrm{C}$ : $\left[\mathrm{EPy}_{\mathrm{B}} \mathrm{BF}_{4}<\right.$ $\left[\mathrm{C}_{18} \mathrm{mim}\right] \mathrm{BF}_{4}<\left[\mathrm{C}_{2} \mathrm{mim}\right] \mathrm{BF}_{4}<[\mathrm{C} 4 \mathrm{mim}] \mathrm{BF}_{4}<$ $[\mathrm{EPy}] \mathrm{PF}_{6}<\left[\mathrm{C}_{2} \mathrm{mim}\right] \mathrm{PF}_{6}$, which is in agreement with the order of onset temperature in DSC result.

The curing behavior of different 3BOCN/ILs blends discussed above were investigated by TGA, DSC and rheological analysis. And these data all revealed that PN curing behavior changed with the structures of ILs. According to the experimental result, we can sum up a ranking of ILs catalytic activity: $\left[\mathrm{EPy}_{\mathrm{B}} \mathrm{BF}_{4}>\left[\mathrm{C}_{18} \mathrm{mim}\right] \mathrm{BF}_{4}>\left[\mathrm{C}_{2} \mathrm{mim}\right] \mathrm{BF}_{4}>\right.$ $\left[\mathrm{C}_{4} \mathrm{mim}\right] \mathrm{BF}_{4}>[\mathrm{EPy}] \mathrm{PF}_{6}>\left[\mathrm{C}_{2} \mathrm{mim}\right] \mathrm{PF}_{6}$. The physic and chemical properties of ILs vary with some structural factors (anion, cation, alkyl chain length at cation) [25-31]. These factor also play decisive roles on the catalytic activity of ILs to PN curing. Firstly, it is obvious that ILs with $\left[\mathrm{BF}_{4}\right]$ have much better curing efficiency than $\left[\mathrm{PF}_{6}\right]$, suggesting the dominating influence of the anion on catalytic activity. Besides the anion, the cation has a strong influence too. ILs with [EPy] cations are more efficient than those with $\left[\mathrm{C}_{2} \mathrm{mim}\right]$ cation: $[\mathrm{EPy}] \mathrm{BF}_{4}>$ $\left[\mathrm{C}_{2} \mathrm{mim}\right] \mathrm{BF}_{4},[\mathrm{EPy}] \mathrm{PF}_{6}>\left[\mathrm{C}_{2} \mathrm{mim}\right] \mathrm{PF}_{6}$. Moreover, the catalytic activity is relative to alkyl chain length at cation: $\left[\mathrm{C}_{18} \mathrm{mim}\right] \mathrm{BF}_{4}>\left[\mathrm{C}_{2} \mathrm{mim}_{\mathrm{B}} \mathrm{BF}_{4}>\right.$ $[\mathrm{C} 4 \mathrm{mim}] \mathrm{BF}_{4}$, which is similar to the relationship between melting point and alkyl chain length at cation: when the alkyl chains at cation become larger, the electrostatic forces between cation and anion decreas, resulting in lower melting point, but when the alkyl chains are greater than a certain length, the Van der Waals forces play an important part, resulting in the increase in melting point. $\left(\left[\mathrm{C}_{18} \mathrm{mim}^{\circ} \mathrm{BF}_{4}: 60.5^{\circ} \mathrm{C}\right.\right.$, $\left.\left[\mathrm{C}_{2} \mathrm{mim}\right] \mathrm{BF}_{4}: 15^{\circ} \mathrm{C},\left[\mathrm{C}_{4} \mathrm{mim}\right] \mathrm{BF}_{4}:-71^{\circ} \mathrm{C}\right)$ [31]. In a word, the structures of ILs have an effect on curing behavior, the effect may be related to interaction

Table 3. The data of 3BOCN/ILs (molar ratio 1.255:1) gelation point in dynamic viscosity measurements

\begin{tabular}{|l|c|c|c|}
\hline & $\begin{array}{c}\text { Gelation temperature } \\
\text { at heating rate of } \mathbf{5}^{\circ} \mathbf{C} / \mathbf{m i n} \\
{\left[{ }^{\circ} \mathbf{C}\right]}\end{array}$ & $\begin{array}{c}\text { Gelation time } \\
\text { at 260 } \\
{[\mathbf{m i n}]}\end{array}$ & $\begin{array}{c}\text { Gelation time } \\
\text { at 240 } \\
{[\mathbf{m i n}]}\end{array}$ \\
\hline $3 \mathrm{BOCN} /[\mathrm{EPy}] \mathrm{CF}_{4}$ & 306.0 & 25.6 & 40.0 \\
\hline $3 \mathrm{BOCN} /\left[\mathrm{EPy}_{\mathrm{P}} \mathrm{PF}_{6}\right.$ & $>350$ & 174.4 & 207.1 \\
\hline $3 \mathrm{BOCN} /\left[\mathrm{C}_{2} \mathrm{mim}_{\mathrm{B}}\right] \mathrm{BF}_{4}$ & $>350$ & 37.3 & 45.6 \\
\hline $3 \mathrm{BOCN} /\left[\mathrm{C}_{2} \mathrm{mim}\right] \mathrm{PF}_{6}$ & $>350$ & $>500$ & $>500$ \\
\hline $3 \mathrm{BOCN} /\left[\mathrm{C}_{4} \mathrm{mim}\right] \mathrm{BF}_{4}$ & $>350$ & 65.0 & 100.0 \\
\hline $3 \mathrm{BOCN} /\left[\mathrm{C}_{18} \mathrm{mim}\right] \mathrm{BF}_{4}$ & 319.7 & 30.5 & 42.5 \\
\hline
\end{tabular}



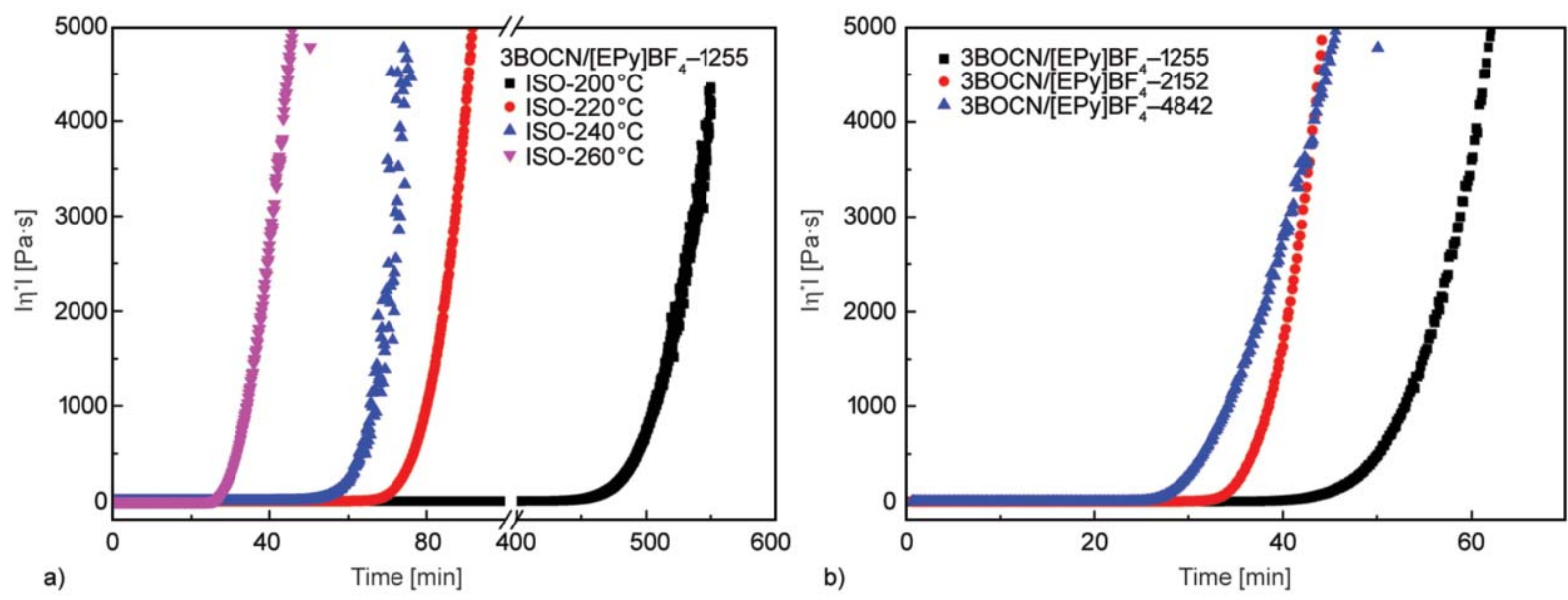

Figure 5. Melt viscosity vs. time cure for $\left.3 \mathrm{BOCN}^{-[} \mathrm{EPy}^{\mathrm{B}}\right] \mathrm{BF}_{4}$ blend (a) at various temperature in 1.255:1 mass ratio, (b) in $1.255: 1,2.152: 2,4.842: 1$ molar ratios at $260^{\circ} \mathrm{C}$

between anion and cation and charge distribution in them.

Rheometric studies on 3BOCN/[EPy] $\mathrm{BF}_{4}$ blend were also conducted to learn about the influence of IL concentration and heating temperature on the curing behavior. Melt viscosity increase as a function of reaction time for polymerization of $3 \mathrm{BOCN} /[\mathrm{EPy}] \mathrm{BF}_{4}$ at $200,220,240$ and $260^{\circ} \mathrm{C}$ in $1.255: 1$ mass ratio are shown in Figure 5a, and 3BOCN/[EPy] $\mathrm{BF}_{4}$ in 1.255:1, 2.152:1, 4.842:1 molar ratios at $260^{\circ} \mathrm{C}$ are shown in Figure $5 \mathrm{~b}$. From the curves, it is evident that the blends can keep in low viscosity for a long time. And as expected, the higher the temperature or the higher the content of IL, the faster the rate of viscosity increased.

\subsection{Properties of polymer network \\ 3.2.1. FT-IR}

To observe the polymerization reaction and polymer structure, IR measurement was conducted on 3BOCN/ $[\mathrm{EPy}] \mathrm{BF}_{4}$ cured at elevated temperatures, as shown in Figure 6. Nitrile group absorption peak at around $2230 \mathrm{~cm}^{-1}$ for 3 BOCN was evidently weakened. Meanwhile new strong absorption peak at around 1520 and $1360 \mathrm{~cm}^{-1}$ assigned to triazine was observed. Moreover, typical isoindoline peak at $1720 \mathrm{~cm}^{-1}$ was

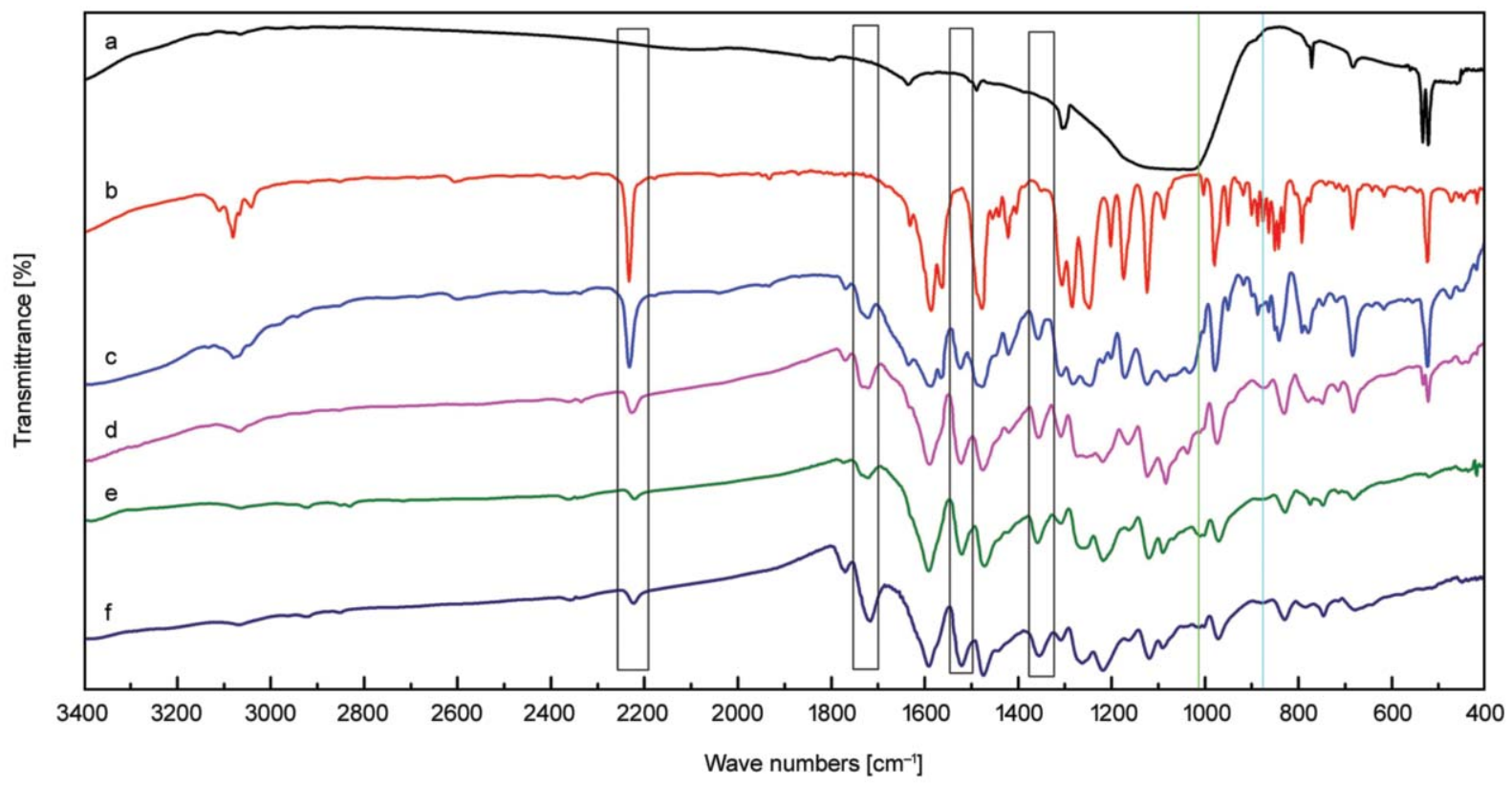

Figure 6. IR spectra of $3 \mathrm{BOCN},[\mathrm{EPy}] \mathrm{BF}_{4}$ and polymers $\left(3 \mathrm{BOCN} /[\mathrm{EPy}] \mathrm{BF}_{4}\right.$ molar ratio 2.152:1) cured at elevated temperatures. (a) $\left[\mathrm{EPy}_{\mathrm{BBF}}\right.$; (b) $3 \mathrm{BOCN}$; (c) $240^{\circ} \mathrm{C}$ for $8 \mathrm{~h}$; (d) $240^{\circ} \mathrm{C}$ for $8 \mathrm{~h}, 245^{\circ} \mathrm{C}$ for $8 \mathrm{~h}, 270^{\circ} \mathrm{C}$ for $8 \mathrm{~h}$; (e) $240^{\circ} \mathrm{C}$ for $8 \mathrm{~h}, 245^{\circ} \mathrm{C}$ for $8 \mathrm{~h}, 270^{\circ} \mathrm{C}$ for $8 \mathrm{~h}, 295^{\circ} \mathrm{C}$ for $8 \mathrm{~h}, 320^{\circ} \mathrm{C}$ for $8 \mathrm{~h}$; (f) $220^{\circ} \mathrm{C}$ for $8 \mathrm{~h}, 245^{\circ} \mathrm{C}$ for $8 \mathrm{~h}, 270^{\circ} \mathrm{C}$ for $8 \mathrm{~h}, 295^{\circ} \mathrm{C}$ for $8 \mathrm{~h}, 320^{\circ} \mathrm{C}$ for $8 \mathrm{~h}, 350^{\circ} \mathrm{C}$ for $8 \mathrm{~h}, 380^{\circ} \mathrm{C}$ for $8 \mathrm{~h}$. 


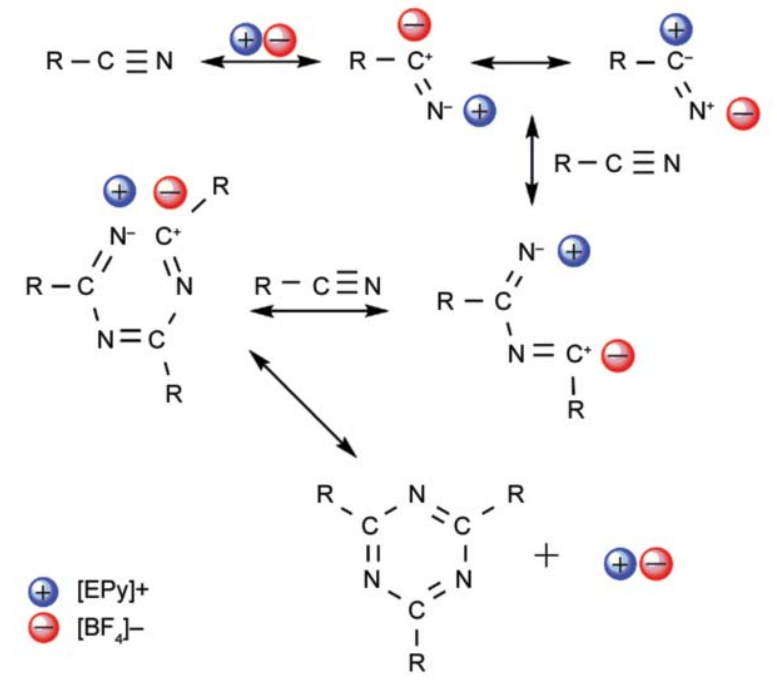

Figure 7. Probable curing mechanism of $3 \mathrm{BOCN}^{-[\mathrm{EPy}] \mathrm{BF}_{4}}$ system

also observed [32]. However, peak assigned to characteristic absorptions representative of phthalocynine $\left(1010 \mathrm{~cm}^{-1}\right)$ [33] formation can be hardly found. Additionally, the peak of nitrile group became weaker gradually with the curing degree, and there was still residual nitrile group even after post-cured of $3 \mathrm{BOCN} /[\mathrm{EPy}] \mathrm{BF}_{4}$ system, which may due to the steric hindrance of the unreacted nitrile groups at the ortho-position of triazine ring [34]. Figure 7 showed the probable curing mechanism of $3 \mathrm{BOCN} /$ $\left[\mathrm{EPy}_{\mathrm{B}}\right] \mathrm{BF}_{4}$ system.

\subsubsection{Thermal and dynamic mechanical properties}

The thermal and thermal-oxidative stability of postcured $3 \mathrm{BOCN} /[\mathrm{EPy}] \mathrm{BF}_{4}$ resins was investigated by TGA in nitrogen and air atmosphere at a heating rate of $10^{\circ} \mathrm{C} / \mathrm{min}$. Figure 8 a showed the thermal stability

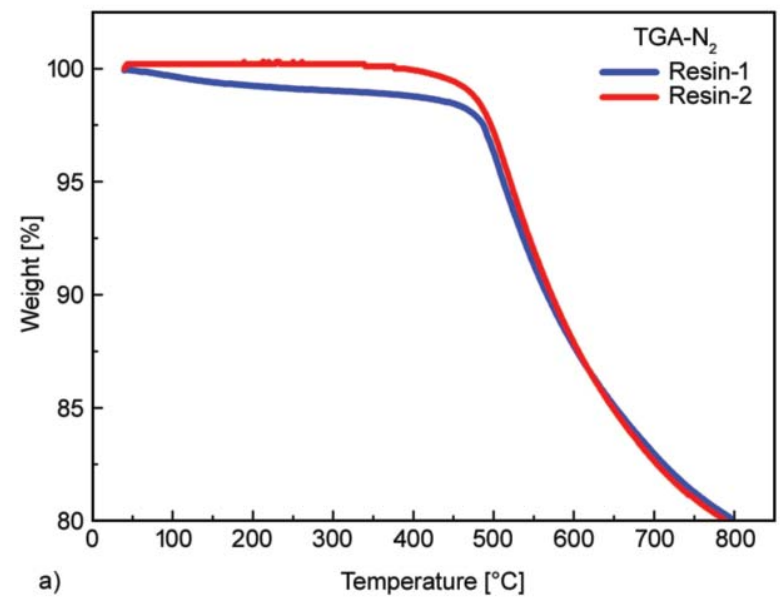

of cured resin samples in different mass ratio under $\mathrm{N}_{2}$ atmosphere. The thermal stability of the cured Resin-1 (3BOCN/[EPy]BF 4 molar ratio 4.842:1) and Resin-2 (3BOCN/[EPy]BF 4 molar ratio 2.152:1) were close and both of them exhibited excellent thermal stability up to $450^{\circ} \mathrm{C}$ in $\mathrm{N}_{2}$ and their $T_{5}$ and $T_{10}$ are higher than 512 and $567^{\circ} \mathrm{C}$ respectively. Particularly, the char yield of these resin reached up to $80 \%$ (Table 4), suggesting that the phthalonitrile resins cure by ionic liquids have outstanding thermal stability and may be excellent carbon precursors ${ }^{7}$. The cured resins also exhibited good thermal-oxidative stability in air atmosphere as showed in Figure $8 \mathrm{~b}$. Both of Resin- 1 and Resin- 2 show thermaloxidative stability to about $480^{\circ} \mathrm{C}$. But when the temperature was higher than $500^{\circ} \mathrm{C}$, the Resin-2 decomposed faster than Resin-1 and they finally had char yield of 21.3 and $44.1 \%$ respectively, which might due to the higher content of ILs in Resin-2. In a word, the data of TGA shows that the thermal and thermos-oxidative stability of $3 \mathrm{BOCN} /[\mathrm{EPy}] \mathrm{BF}_{4}$ system are excellent and rank the highest value compared with other curing system $[13,18,19]$.

DMA were performed on Resin-1 and Resin-2 in $\mathrm{N}_{2}$ atmosphere. We observed (Figure 9) that the storage modulus of the two resins gradually decreased from 40 to $450^{\circ} \mathrm{C}$, while this decrease didn't result in complete loss of mechanical properties at elevated temperature, which is evidence for the good high-temperature mechanical properties. Meanwhile, no peak of $T_{\mathrm{g}}$ was observed in tan $\delta$ curves, indicating $T_{\mathrm{g}}$ of the two resins are higher than $450^{\circ} \mathrm{C}$. During the heating process between 40 and $400^{\circ} \mathrm{C}$, the storage modulus of Resin-1 changed from 3930 to $1280 \mathrm{MPa}$, while the storage modulus of Resin-2 changed from 3588

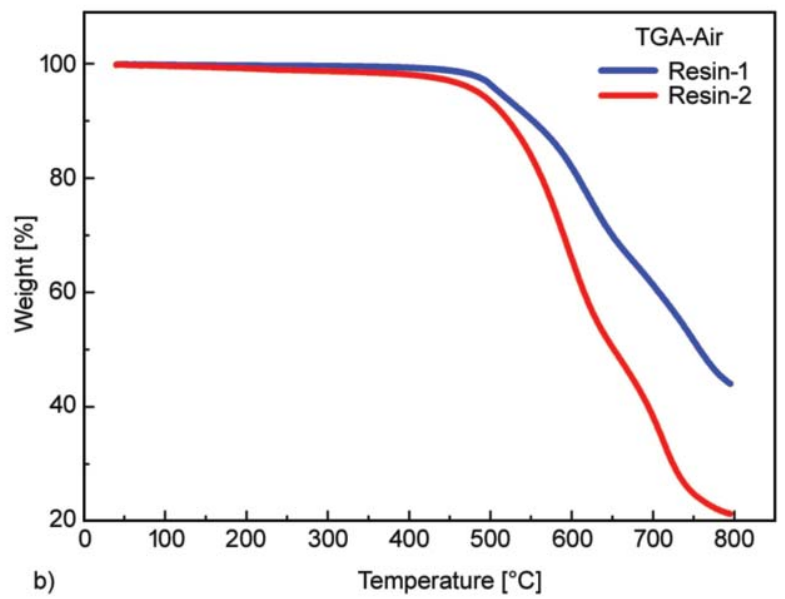

Figure 8. TGA curves of 3BOCN/[EPy] $\mathrm{BF}_{4}$ (Resin-1 4.842:1 molar ratio; Resin-2 2.152:1 molar ratio) post-cured resins at the heating rate of $10^{\circ} \mathrm{C} / \min$ in (a) $\mathrm{N}_{2}$, (b) air 
Table 4. TGA data of 3BOCN/[EPy]BF4 (Resin-1 4.842:1 molar ratio; Resin-2 2.152:1 molar ratio) post-cured resins at the heating rate of $10^{\circ} \mathrm{C} / \mathrm{min}$ in $\mathrm{N}_{2}$ and air.

\begin{tabular}{|c|c|c|c|c|c|c|}
\hline \multirow[b]{2}{*}{ Resins } & \multicolumn{3}{|c|}{ TGA in $\mathbf{N}_{2}$} & \multicolumn{3}{|c|}{ TGA in air } \\
\hline & $\begin{array}{c}T_{5} \\
{\left[{ }^{\circ} \mathbf{C}\right]}\end{array}$ & $\begin{array}{c}T_{10} \\
{\left[{ }^{\circ} \mathrm{C}\right]}\end{array}$ & $\begin{array}{c}\text { Char yield at } 800^{\circ} \mathrm{C} \\
{[\%]}\end{array}$ & $\begin{array}{c}T_{5} \\
{\left[{ }^{\circ} \mathbf{C}\right]}\end{array}$ & $\begin{array}{c}T_{10} \\
{\left[{ }^{\circ} \mathrm{C}\right]}\end{array}$ & $\begin{array}{c}\text { Char yield at } 800^{\circ} \mathrm{C} \\
{[\%]}\end{array}$ \\
\hline Resin-1 & 512.4 & 566.9 & 80.1 & 505.5 & 541.6 & 32.3 \\
\hline Resin-2 & 520.7 & 572.2 & 80.0 & 485.1 & 522.2 & 21.3 \\
\hline
\end{tabular}

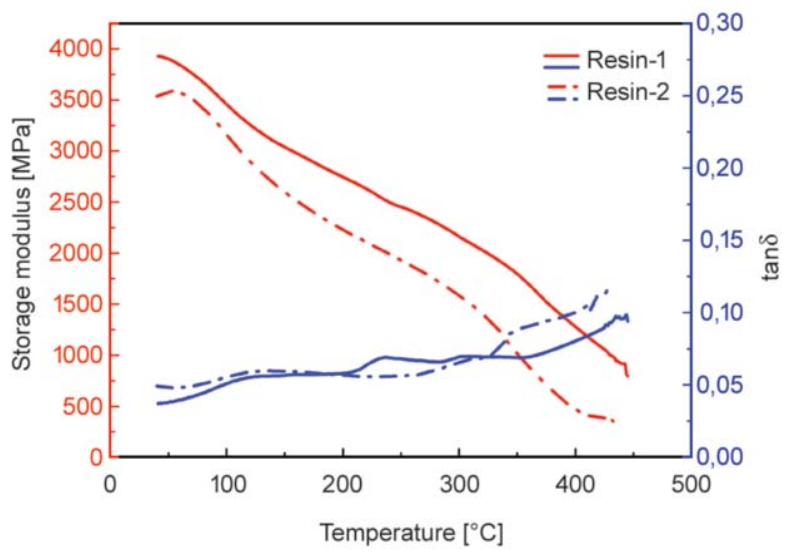

Figure 9. Dynamic mechanical properties of 3BOCN/ [EPy]BF 4 (Resin-1 4.842:1 molar ratio; Resin-2 2.152:1 molar ratio) post-cured resins

to $480 \mathrm{MPa}$. The relatively lower storage modulus of Resin-2 may due to that the residual IL in Resin-2 was more and acted as plasticizers.

\subsubsection{Dielectric property}

As a kind of salt melt at room temperature, the curing agent $[\mathrm{EPy}] \mathrm{BF}_{4}$ may bring some changes in dielectric property to cured resins. The dielectric constant $\left(\varepsilon^{\prime}\right)$ and dielectric loss $(\tan \delta)$ as a function of frequency for samples in room temperature were illustrated in Figure 10. The result suggested that the dielectric constant of these resins were very high at low frequency and decreased sharply with the increase of frequency from $10^{-2}$ to $10^{5} \mathrm{~Hz}$ and kept in range of 6.6 5.1 in frequency from $10^{5} \sim 10^{7} \mathrm{~Hz}$. The dielectric $\operatorname{loss}(\tan \delta)$ values of these resins also showed similar decrease trend, but there were peaks at $1.63 \cdot 10^{2}$ and $1 \cdot 10^{3} \mathrm{~Hz}$ in curves of Resin- 1 and Resin-2 respectively, which might due to that the IL caused heterogeneous phase in resins. Finally, the $\tan \delta$ of the two resins decreased to about 0.03 in high frequency.

From the data of $\varepsilon^{\prime}$ and $\tan \delta$, it can be concluded that the introduction of ionic liquid had significant effect on the dielectric properties of phthalonitrile resins and this effect changed with content of IL. The high dielectric constant and unique dielectric loss were brought to $3 \mathrm{BOCN} / \mathrm{IL}$ resins by ILs, and these resins may be potential candidates for electronic industry and military applications [35], such as electrochemical devices, capacitors, active vibration control, aerospace, underwater navigation and surveillance, etc. $[36,37]$

Additionally, the effect of IL content on the DMA and Dielectric data corresponded to the above-mentioned probable curing mechanism of $3 \mathrm{BOCN} /$ $[\mathrm{EPy}] \mathrm{BF}_{4}$ system.
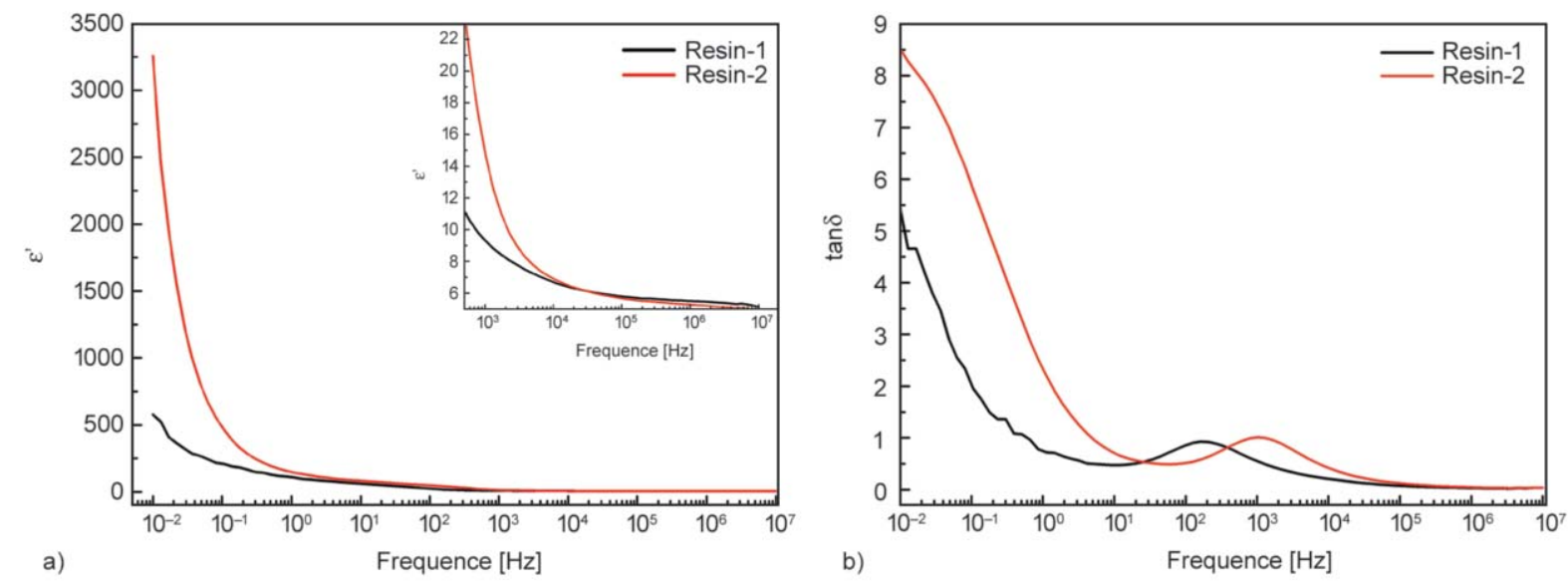

Figure 10. Dielectric constant curves (a) and dielectric loss curves (b) of 3BOCN/[EPy]BF 4 (Resin-1 4.842:1 molar ratio; Resin-2 2.152:1 molar ratio) post-cured resins 


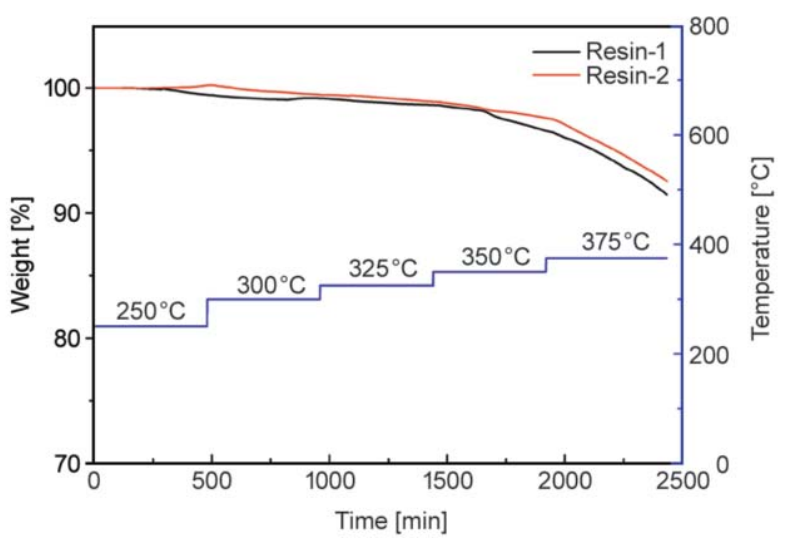

Figure 11. Long-term aging of 3BOCN/[EPy] BF 4 (Resin-1 4.842:1 molar ratio; Resin-2 2.152:1 molar ratio) post-cured resins

\subsubsection{Long-term aging and water absorption capability}

The effect of long-term aging or heating at high temperatures under air is a very important factor in the practical use of PN resins under real world conditions. We simulated these conditions in TGA by subjecting samples (in $1.5 \times 1.5 \times 1.5 \mathrm{~mm}^{3}$ ) to stepwise heating at a series of temperatures between 250 and $375^{\circ} \mathrm{C}$ at $8 \mathrm{~h}$ temperature intervals in flowing air ( $60 \mathrm{ml} / \mathrm{min}$ ). Figure 11 and Table 5 show long-term aging data for Resin-1 and Resin-2. Upon heating from 250 to $350{ }^{\circ} \mathrm{C}$, a cumulative weight loss of 3.42 and $2.40 \%$ was observed for Resin- 1 and Resin-2, respectively. When the resins were further heated to $375^{\circ} \mathrm{C}$, the oxidative destruction of them became faster, and finally a cumulative weight loss of 8.52 and $7.44 \%$ was observed at the end of this experiment. Although the initial decomposition temperature of neat ILs are below $350^{\circ} \mathrm{C}$, the resins cured by ILs could keep stable at $350^{\circ} \mathrm{C}$ for a long time. On the other hand, although the content of ILs in Resin-2 (20\% mass fraction) was the double of Resin-1 (10\% mass fraction), the aging results showed that the long-term oxidative stability of Resin-2 was close to Resin- 1 and even better, this phenomenon indicated that PN resins cured by ILs in proper content could bear long-term aging at high temperature under air.

Another important aspect of PN resins is their water absorption capability [34]. Samples of Resin-1 and Resin-2 were dried in a vacuum oven at $120^{\circ} \mathrm{C}$ for $24 \mathrm{~h}$ before water absorption studies. Then they were heated in distilled water for $48 \mathrm{~h}$ at $100^{\circ} \mathrm{C}$, and the
Table 5. Long-term aging data of $3 \mathrm{BOCN} /\left[\mathrm{EPy}_{\mathrm{BBF}}\right.$ (Resin-1 4.842:1 molar ratio; Resin-2 2.152:1 molar ratio) post-cured resins.

\begin{tabular}{|l|c|c|c|c|c|}
\hline \multirow{2}{*}{ Samples } & \multicolumn{5}{|c|}{$\begin{array}{c}\text { Total weight loss } \\
\text { [wt\%] }\end{array}$} \\
\cline { 2 - 6 } & $\mathbf{2 5 0}$ & $\mathbf{3 0 0}$ & $\mathbf{3 2 5}$ & $\mathbf{3 5 0}$ & $\mathbf{3 7 5}$ \\
\hline Resin-1 & 0.00 & 0.82 & 1.36 & 3.42 & 8.52 \\
\hline Resin-2 & 0.00 & 0.53 & 1.09 & 2.40 & 7.44 \\
\hline
\end{tabular}

weight increases were noted. The maximum amount of water absorbed over this time period were approximately 3.24 and $6.89 \%$ by weight for Resin- 1 and Resin-2, respectively, which were relatively higher than PN cured by aromatic diamine [1]. The result indicated that the content of [EPy]BF 4 , as a kind of ILs easy to absorb water, has an influence on the water absorption of resulting resins. So we may be able to limit the water absorption capabilities of PN resins by changing the mass ratio of ILs or choosing some ILs that have higher hydrophobicity, e.g. $\left[\mathrm{C}_{18} \mathrm{mim}\right] \mathrm{BF}_{4}$.

\section{Conclusions}

Ionic liquids were used as a new class of curing agent to promote the curing reaction of phthalonitrile monomers. Some kind of ILs with different cation or anion were blended with $3 \mathrm{BOCN}$, and the study on curing behavior of 3BOCN/ILs blends suggested that the structures of ILs (anion, cation and alkyl chain length at cation) had a great impact on the catalytic activity.

The $3 \mathrm{BOCN} /[\mathrm{EPy}] \mathrm{BF}_{4}$ resins were prepared at elevated temperature. IR showed that the nitrile group absorption peak was weakened, meanwhile triazine and isoindoline were formed in curing process. The prepared resins exhibited excellent thermal stability and long term oxidative stability together with high storage modulus and high $T_{\mathrm{g}}$. And the high dielectric constant and unique dielectric loss make these resins the potential materials in electronic industry and military applications. And the water absorption capabilities of PN resins may be controllable by changing consumption and the kinds of ILs.

This study may open up a new research direction of the PN modification.

\section{Acknowledgements}

The authors sincerely thank to the National Natural Science Foundation of China (No. 51203098) for the financial support. 


\section{References}

[1] Laskoski M., Neal A., Keller T. M., Dominguez D. D., Klug C. A., Saab A. P.: Improved synthesis of oligomeric phthalonitriles and studies designed for low temperature cure. Journal of Polymer Science Part A: Polymer Chemistry, 52, 1662-1668 (2014).

https://doi.org/10.1002/pola.27161

[2] Dominguez D. D., Keller T. M.: Properties of phthalonitrile monomer blends and thermosetting phthalonitrile copolymers. Polymer, 48, 91-97 (2007). https://doi.org/10.1016/j.polymer.2006.11.003

[3] Zeng K., Yang G.: Phthalonitrile matrix resins and composites. in 'Wiley encyclopedia of composites' (eds.: Nicolais L., Borzacchiello A., Lee S. M.) Wiley, New York, 1-14 (2012).

https://doi.org/10.1002/9781118097298.weoc169

[4] Sastri S. B., Armistead J. P., Keller T. M.: Phthalonitrile-carbon fiber composites. Polymer Composites, 17, 816-822 (1996). https://doi.org/10.1002/pc.10674

[5] Keller T. M., Roland C. M.: High temperature adhesive. U.S. Patent 5242755, USA (1993).

[6] Keller T. M.: Phthalonitrile-based conductive polymer. Journal of Polymer Science Part A: Polymer Chemistry, 25, 2569-2576 (1987).

https://doi.org/10.1002/pola.1987.080250921

[7] Laskoski M., Keller T. M., Qadri S. B.: Direct conversion of highly aromatic phthalonitrile thermosetting resins into carbon nanotube containing solids. Polymer, 48, 7484-7489 (2007).

https://doi.org/10.1016/j.polymer.2007.11.003

[8] Keller T. M.: Strong organic acid cured phthalonitrile resins for high temperature applications. Polymer Preprints, 33, 422-423 (1992).

[9] Burchill P. J.: On the formation and properties of a hightemperature resin from a bisphthalonitrile. Journal of Polymer Science Part A: Polymer Chemistry, 32, 1-8 (1994).

https://doi.org/10.1002/pola.1994.080320101

[10] Keller T. M., Griffith J. R.: The synthesis of a new class of polyphthalocyanine resins. ACS Symposium Series, 132, 25-34 (1980). https://doi.org/10.1021/bk-1980-0132.ch003

[11] Walton T. R., Griffith J. R., O'Rear J. G.: Phthalocyanine resins: A new class of thermally stable resins for adhesives, coatings, and plastics. in 'Adhesion science and technology', Plenum Press, New York, 665-676 (1975).

[12] Hu J., Liu Y., Jiao Y., Ji S., Sun R., Yuan P., Zeng K., Yang G.: Self-promoted phthalimide-containing phthalonitrile resins with sluggish curing process and excellent thermal stability. RSC Advances, 5, 16199 16206 (2015).

https://doi.org/10.1039/C4RA17306F

[13] Keller T. M., Dominguez D. D.: High temperature resorcinol-based phthalonitrile polymer. Polymer, 46, 4614-4618 (2005).

https://doi.org/10.1016/j.polymer.2005.03.068
[14] Laskoski M., Schear M. B., Neal A., Dominguez D. D., Ricks-Laskoski H. L., Hervey J., Keller T. M.: Improved synthesis and properties of aryl ether-based oligomeric phthalonitrile resins and polymers. Polymer, 67, 185191 (2015).

https://doi.org/10.1016/j.polymer.2015.04.071

[15] Laskoski M., Dominguez D. D., Keller T. M.: Alkynecontaining phthalonitrile resins: Controlling mechanical properties by selective curing. Journal of Polymer Science Part A: Polymer Chemistry, 51, 4774- 4778 (2013). https://doi.org/10.1002/pola.26899

[16] Xu M., Liu M., Dong S., Liu X.: Design of low temperature self-cured phthalonitrile-based polymers for advanced glass fiber composite laminates. Journal of Materials Science, 48, 8108-8116 (2013).

https://doi.org/10.1007/s10853-013-7623-Z

[17] Wu D., Zhao Y., Zeng K., Yang G.: A novel benzimidazole-containing phthalonitrile monomer with unique polymerization behavior. Journal of Polymer Science Part A: Polymer Chemistry, 50, 4977-4982 (2012).

https://doi.org/10.1002/pola.26331

[18] Ji S., Yuan P., Hu J., Sun R., Zeng K., Yang G.: A novel curing agent for phthalonitrile monomers: Curing behaviors and properties of the polymer network. Polymer, 84, 365-370 (2016).

https://doi.org/10.1016/j.polymer.2016.01.006

[19] Yuan P., Ji S., Hu J., Hu X., Zeng K., Yang G.: Systematic study on highly efficient thermal synergistic polymerization effect between alicyclic imide moiety and phthalonitrile: Scope, properties and mechanism. Polymer, 102, 266-280 (2016).

https://doi.org/10.1016/j.polymer.2016.09.025

[20] Welton T.: Room-temperature ionic liquids. Solvents for synthesis and catalysis. Chemical Reviews, 99, 2071-2084 (1999).

https://doi.org/10.1021/cr980032t

[21] Plechkova N. V., Seddon K. R.: Applications of ionic liquids in the chemical industry. Chemical Society Reviews, 37, 123-150 (2008).

https://doi.org/10.1039/B006677J

[22] Wasserscheid P., Welton T.: Ionic liquids in synthesis. Wiley, Hoboken (2008).

[23] Mąka H., Spychaj T., Zenker M.: High performance epoxy composites cured with ionic liquids. Journal of Industrial and Engineering Chemistry, 31, 192-198 (2015). https://doi.org/10.1016/j.jiec.2015.06.023

[24] Sanes J., Saurín N., Carrión F. J., Ojados G., Bermúdez, M. D.: Synergy between single-walled carbon nanotubes and ionic liquid in epoxy resin nanocomposites. Composites Part B: Engineering, 105, 149-159 (2016). https://doi.org/10.1016/j.compositesb.2016.08.044

[25] Carmichael A. J., Seddon K. R.: Polarity study of some 1-alkyl-3-methylimidazolium ambient-temperature ionic liquids with the solvatochromic dye, Nile Red. Journal of Physical Organic Chemistry, 13, 591-595 (2000). https://doi.org/10.1002/1099-1395(200010)13:10<591::AIDPOC $305>3.0 . \mathrm{CO} ; 2-2$ 
[26] Tokuda H., Hayamizu K., Ishii K., Susan M. A. B. H., Watanabe M.: Physicochemical properties and structures of room temperature ionic liquids. 1. Variation of anionic species. The Journal of Physical Chemistry B, 108, 16593-16600 (2004).

https://doi.org/10.1021/jp047480r

[27] Turner E. A., Pye C. C., Singer R. D.: Use of ab initio calculations toward the rational design of room temperature ionic liquids. The Journal of Physical Chemistry A, 107, 2277-2288 (2003).

https://doi.org/10.1021/jp021694w

[28] Katritzky A. R., Jain R., Lomaka A., Petrukhin R., Karelson M., Visser A. E., Rogers R. D.: Correlation of the melting points of potential ionic liquids (imidazolium bromides and benzimidazolium bromides) using the CODESSA program. Journal of Chemical Information and Computer Sciences, 42, 225-231 (2005).

https://doi.org/10.1021/ci049691z

[29] Stefaniak W., Janus E., Milchert E.: Diels-Alder reaction of cyclopentadiene and alkyl acrylates in the presence of pyrrolidinium ionic liquids with various anions. Catalysis Letters, 141, 742-747 (2011). https://doi.org/10.1007/s10562-011-0558-6

[30] Cao Y., Chen Y., Sun X., Zhang Z., Mu T.: Water sorption in ionic liquids: Kinetics, mechanisms and hydrophilicity. Physical Chemistry Chemical Physics, 14, 12252-12262 (2012). https://doi.org/10.1039/C2CP41798G

[31] Ngo H. L., LeCompte K., Hargens L., McEwen A. B.: Thermal properties of imidazolium ionic liquids. Thermochimica Acta, 357, 97-102 (2000). https://doi.org/10.1016/S0040-6031(00)00373-7
[32] Balogh-Hergovich É., Speier G., Réglier M., Giorgi M., Kuzmann E., Vértes A.: Synthesis, structure and spectral properties of a novel stable homoleptic iron(II) complex of 1,3-bis(2'-pyridylimino)isoindoline, $\mathrm{Fe}(\mathrm{ind})_{2}$. Inorganic Chemistry Communications, 8, 457-459 (2005). https://doi.org/10.1016/j.inoche.2005.02.013

[33] Seoudi R., El-Bahy G. S., El Sayed Z. A.: FTIR, TGA and DC electrical conductivity studies of phthalocyanine and its complexes. Journal of Molecular Structure, 753, 119-126 (2005). https://doi.org/10.1016/j.molstruc.2005.06.003

[34] Snow A. W., Griffith J. R., Marullo N. P.: Syntheses and characterization of heteroatom-bridged metal-free phthalocyanine network polymers and model compounds. Macromolecules, 17, 1614-1624 (1984). https://doi.org/10.1021/ma00138a033

[35] Dang Z-M., Yuan J-K., Zha J-W., Zhou T., Li S-T., Hu G-H.: Fundamentals, processes and applications of high-permittivity polymer-matrix composites. Progress in Materials Science, 57, 660-723 (2012). https://doi.org/10.1016/j.pmatsci.2011.08.001

[36] Bar-Cohen Y.: Electroactive polymers as artificial muscles: A review. Journal of Spacecraft and Rockets, 39, 822-827 (2002).

https://doi.org/10.2514/2.3902

[37] Uchino K.: Piezoelectric actuators and ultrasonic motors. in 'Electronic materials: Science and technology' (ed.: Tuller H. L.) Springer, New York (1997). 